International Journal of Human Resource Management, Volume 25, Issue 16, 2014, pp. 2295-2318 DOI: $10.1080 / 09585192.2013 .877058$

Maike Andresen, Franziska Bergdolt, Jil Margenfeld, \& Michael Dickmann

\title{
Addressing international mobility confusion - developing definitions and differentiations for self-initiated and assigned expatriates as well as migrants
}

\begin{abstract}
Please cite as: Andresen, M., Bergdolt, F., Margenfeld, J., \& Dickmann, M. (2014). Addressing international mobility confusion - Developing definitions and differentiations for self-initiated and assigned expatriates as well as migrants. International Journal of Human Resource Management, 25(16), 2295-2318. doi: $10.1080 / 09585192.2013 .877058$
\end{abstract}

\begin{abstract}
The literature on international human resource management indicates a growing array of different forms of international work experiences such as assigned and self-initiated expatriation. However, the criteria for demarcation of these different forms and the term 'migrant' are often unclear which leads to an unfortunate lack of comparability of research and a potential confusion for readers. Based on the sociological, psychological and economics literature, this article reviews and synthesizes the existing definitions of the three terms in the current research. A qualitative content analysis and the Rubicon model [Heckhausen, H., and Gollwitzer, P.M. (1987), 'Thought Contents and Cognitive Functioning in Motivational Versus Volitional States of Mind', Motivation and Emotion, 1, $101-120$.] are used as a theoretical base to structure the findings. The paper creates a criteria-based definition and differentiation of terms and then develops a typology of four different types of expatriates: assigned expatriates, inter-self-initiated expatriates, intra-self-initiated expatriates and drawn expatriates. Implications for management as well as for future research are outlined.
\end{abstract}

Keywords: assigned expatriate; drawn expatriate; expatriate typology; migrant; qualitative content analysis; self-initiated expatriate

\section{Introduction}

International mobility has seen a substantial increase in interest through recent academic work. The literature on international human resource management indicates a growing array of different forms of international work experiences (Briscoe, Schuler and Claus 2009; Selmer and Lauring 2011b). However, the criteria for demarcation of these different forms are often unclear (Baruch, Dickmann, Altman and Bournois 2013; Doherty 2013) which leads to an unfortunate lack of comparability of research and a potential confusion for readers. In particular, the terms 'self-initiated expatriation' (SIE), 'assigned expatriation' (AE) and 'migration' seem to be overlapping and are often applied interchangeably in current expatriation research.

Several authors agree on the difference between the terms 'assigned expatriate', denoting an employee who is sent abroad by his/her ${ }^{1}$ company, usually receiving an expatriate contract and the 'self-initiated expatriate', meaning an individual who undertakes his international work experience with little or no organizational sponsorship, often with a less favorable local work contract (Suutari and Brewster 2000; Peltokorpi and Froese 2009; Biemann and Andresen 2010). However, confusion exists on how to deal with company-sponsored expatriates who initiated the move abroad themselves with many researchers simply treating these as AEs (Sparrow, Brewster and Harris 2004). While this may capture the effects of the support these individuals gain from their organizations, it is not likely to be nuanced enough in areas such as motivations to work 
abroad (Doherty, Dickmann and Mills 2011). Below, we argue the point and provide criteria on how to further differentiate SIEs into intra-organizational SIEs (Intra-SIEs) remaining in their employing organization and inter-organizational SIEs (Inter-SIEs) changing their employers (Andresen, Bergdolt and Margenfeld 2012).

Moreover, the difference between the terms AE, SIE and migrant seems to be less evident (Al Ariss 2010). In general, international migration can be defined as physical movement from one geographic point to another (Agozino 2000), crossing national borders (Boyle, Halfacree and Robinson 1998). The UN specifies a migrant as 'any person who changes his or her country of usual residence' (United Nations 1998, p. 17), with the 'country of usual residence' representing the place where the person has the center of his life (United Nations 1998). To date, there are only a few articles in the expatriation literature that demarcate the terms AE, SIE and migrant (Briscoe et al. 2009; Al Ariss 2010; Baruch, Dickmann, Altman and Bournois 2010). Unfortunately, these are not sufficiently based on a systematic literature analysis and are often highly prescriptive.

Therefore, there is a need to uniquely demarcate the terms AE, SIE and migrant by systematically reviewing existing definitions of an AE, SIE and migrant in current research literature, by examining regularities and differences in the application of the three terms and by developing a criteria-based definition and differentiation of them. The Rubicon model of action phases (following Heckhausen and Gollwitzer 1987; Heckhausen and Heckhausen 2010) is used afterwards as a theoretical framework to structure the findings. This will contribute to both research and practice. In research, the demarcation contributes to more clarity in research design as well as to a more precise interpretation and better integration of research results in the future. Moreover, with respect to career management in practice, a clearer demarcation of the different groups of internationally mobile employees, i.e. AEs, Intra- and Inter-SIEs, allows for the development of differentiated corporate HR policies and practices.

This article is organized as follows: first, the literature to demarcate SIEs, AEs and migrants is briefly summarized. Second, a description of the methodologies applied to come to a differentiation of the terms AE, SIE and migrant is provided. Third, the final results of the analysis are presented and discussed. Finally, this article closes with theoretical as well as practical implications of the results and provides suggestions for further research.

\section{Current attempts to demarcate SIEs, AEs and migrants}

A few attempts to demarcate the terms SIE, AE and migrant can be found that differ vastly with respect to the criteria chosen and the results. Baruch et al. (2013) distinguish different modes of international work experiences along seven dimensions (time spent, intensity of international contacts, breadth of interaction, legal context, international work instigator, extent of cultural gap and specific position). According to the authors, the time spent abroad is longer for SIEs than for AEs. Furthermore, SIEs in contrast to AEs are not sponsored by an organization and are less likely to gain objective career benefits from their expatriation. In addition, Baruch et al. (2010) distinguish expatriates from migrants in terms of rights to permanent residency, meaning that an expatriate might become a migrant when gaining citizenship or permanent visa status.

Al Ariss (2010) differentiates the terms SIE and migrant along four main criteria: geographical origin and destination of the internationally mobile, the forced/chosen nature of the movement, the period of stay abroad and the positive or negative connotations of the terms. First, Al Ariss assumes that migrants, in contrast to SIEs, 
might often move from less-developed countries to developed countries. Second, migrants and not SIEs might be rather forced to leave their home country, e.g. because of unemployment. Third, SIEs might be more transient in their movement abroad than migrants who may eventually become permanent migrant workers when deciding to stay in the new country. Last, the term migrant might be referred to in more negative terms (e.g. denoting inferiority) than the term SIE (Al Ariss 2010). In contrast to this dissociation of terms, recent literature on migration indicates the existence of migrant subgroups, for instance, described as 'qualified migrants' (Zikic, Bonache and Cerdin 2010) or 'transnational knowledge workers' (Colic-Peisker 2010), neither including individuals who are forced to move nor individuals who are staying permanently in the host country.

Finally, Briscoe et al. (2009) distinguish between 20 different terms of international work experiences, defining SIEs as 'individuals who travel abroad (usually as tourists or students) but who seek work as they travel and are hired in the foreign location, often by firms from their home country' (Briscoe et al. 2009, p. 169). In contrast, migrants are described as employees who are hired to work in a foreign subsidiary or in the parent company and whose citizenship is in another country (Briscoe et al. 2009).

As the numerous criteria chosen in the above-mentioned articles have not been systematically derived from the literature and the demarcations are not thoroughly documented with sources and empirical evidence, the criteria as well as the results might not be exhaustive and their accuracy needs to be verified. This research gap is the starting point for our literature analysis as described below. We will compile the literature and explore the key definitions and use of the terms. One of the key goals of this paper is to clarify the distinctions, draw up clear definitions and develop a framework of different types of self-initiated and assigned expatriates. These steps have numerous managerial and theoretical implications.

\section{Methodology}

\section{Database}

In order to demarcate the terms AE, SIE and migrant, a sample of articles defining one or several of the different groups of internationally mobile employees was identified using an adapted version of the approach developed by David and Han (2004). For the identification of a relevant sample of studies, the following criteria were used.

1. The data used for the analysis were taken from theoretical and empirical studies in the field of expatriation and migration published in peer-reviewed scholarly journals only. The elimination of book chapters or unpublished works for example served to enhance quality control.

2. The articles were retrieved from the EBSCO Host, PsychINFO and Social Sciences Citation Index databases. In order to ensure that recent strands of research on the topic of expatriation and migration were covered, the review focused on articles published in the years 2005 to 2010. However, as the field of research on SIEs is still emerging and the number of definitions available for the term 'self-initiated expatriate' falls substantially below the number of definitions available for the terms 'expatriate' and 'migrant', the selection of Englishlanguage peer-reviewed journal articles was expanded to cover the period from 1997, when the first article about self-initiated expatriates was published, to 2011.

3 . In order to ensure quality, only journals were taken into consideration with a highaccumulated impact factor from 2005 to 2010 of the respective journals using the 
ISI-index. For SIE, non-listed journals were included due to the limitations in published research mentioned above.

4. Substantive relevance was ensured by requiring that selected articles contain at least one primary keyword in their title or abstract, i.e. 'expatriate' or 'migrant'. This meant that it was highly likely that the selected articles contained a definition of at least one of the groups.

5. Quantity was managed by exclusively selecting articles published in journals that included multiple articles about expatriation or migration and by purposely selecting journals that have the highest number of hits in a full-text search using the search terms 'expatriate' and 'migrant'. We deviated from this fifth criterion with respect to articles about SIE to also include journals in which only one article has been published and also those with a low number of hits.

Due to the extensive usage of the terms 'expatriate' and 'migrant' in the literature, the analysis was narrowed down to 10 peer-reviewed journals: five business (HRM) and psychological journals (serving as a basis for the definitions of 'expatriate') and five sociological journals (serving as a basis for the definitions of 'migrant').

Tables $1-3$ show the number of articles and definitions returned using this methodology with a final sample size of 136 articles. The tables show that these sample articles contain, overall, 246 definitions of the terms 'expatriate' (74), 'self-initiated expatriate' (88) and 'migrant' (84). Not all articles contained a proper definition of all terms and some articles included more than one definition.

\section{Data analysis}

We used content analysis (Mayring 2000) in order to analyze and compare the available definitions of the terms AE, SIE and migrant. Qualitative content analysis serves to systematically gather and evaluate qualitative data and is defined as an empirical analysis of texts within their context (Mayring 2000). The identified meaning units (i.e. definitions of the three terms in journal papers) have been coded verbatim using statistical software (SPSS) while disjointing them in meaningful clauses. The clauses were assigned to 15 categories which were deduced from an evaluation of definitions found in standard business and sociological textbooks as well, as induced from the data. According to

Table 1. Impact factors and number of hits in the databases for the term 'expatriate'.

\begin{tabular}{|c|c|c|c|c|}
\hline & $\begin{array}{l}\text { Accumulated number } \\
\text { of hits for the search } \\
\text { term 'expatriate' in the } \\
\text { chosen data bases } \\
\text { (full-text search) }\end{array}$ & $\begin{array}{c}\text { ISI impact } \\
\text { factor } 2005 \text { - } \\
2010\end{array}$ & $\begin{array}{c}\text { Number of } \\
\text { relevant } \\
\text { articles }\end{array}$ & $\begin{array}{l}\text { Number of } \\
\text { relevant } \\
\text { definitions }\end{array}$ \\
\hline International Journal of HRM & 280 & 1.61 & 51 & 74 \\
\hline Journal of World Business & 64 & 2.82 & 10 & \\
\hline Human Resource Management & 62 & 1.83 & 7 & \\
\hline Career Development International & 33 & $\begin{array}{c}1.31 \\
\text { (not listed in } \\
\text { the years } \\
2005-2009 \text { ) }\end{array}$ & 3 & \\
\hline Journal of Applied Psychology & 24 & 6.73 & 3 & \\
\hline
\end{tabular}


Table 2. Impact factors and number of hits in the databases for the term 'migrant'.

\begin{tabular}{lcccc}
\hline & $\begin{array}{c}\text { Accumulated number } \\
\text { of hits for the search } \\
\text { term 'migrant' in the } \\
\text { chosen data bases } \\
\text { (full-text search) }\end{array}$ & $\begin{array}{c}\text { ISI impact } \\
\text { factor 2005 } \\
2010\end{array}$ & $\begin{array}{c}\text { Number of } \\
\text { relevant } \\
\text { articles }\end{array}$ & $\begin{array}{c}\text { Number of } \\
\text { relevant } \\
\text { definitions }\end{array}$ \\
\hline Journal of Ethnic and & 254 & 1.42 & 7 & 84 \\
Migration Studies & 173 & 1.92 & 16 & \\
$\begin{array}{l}\text { Ethnic and Racial Studies } \\
\text { Social Science \& Medicine }\end{array}$ & 163 & 3.48 & 6 & \\
$\begin{array}{l}\text { Global Networks - A Journal } \\
\text { of Transnational Affairs }\end{array}$ & 88 & 2.02 & 23 & \\
International Migration Review & 64 & 2.15 & 35 & \\
\hline
\end{tabular}

Table 3. Impact factors of the papers relevant for the definition of the term 'self-initiated expatriate'.

\begin{tabular}{|c|c|c|c|}
\hline & $\begin{array}{l}\text { ISI impact factor } \\
2005-2010 \text { (average) }\end{array}$ & $\begin{array}{l}\text { Number of } \\
\text { relevant } \\
\text { articles }\end{array}$ & $\begin{array}{c}\text { Number of } \\
\text { relevant } \\
\text { definitions }\end{array}$ \\
\hline International Journal of HRM & 1.61 & 21 & 88 \\
\hline Career Development International & $\begin{array}{l}1.31(\text { not listed in } \\
\text { the years } 2005-2009)\end{array}$ & 15 & \\
\hline Journal of Managerial Psychology & $\begin{array}{l}2.15 \text { (not listed in } \\
\text { the years } 2005-2007)\end{array}$ & 6 & \\
\hline Cross Cultural Management & Not listed & 6 & \\
\hline Journal of World Business & 2.82 & 5 & \\
\hline Canadian Social Science & Not listed & 5 & \\
\hline Thunderbird International Business Review & Not listed & 4 & \\
\hline Employee Relations & Not listed & 4 & \\
\hline Human Resource Management & 1.83 & 3 & \\
\hline $\begin{array}{l}\text { International Studies of Management } \\
\& \text { Organization }\end{array}$ & Not listed & 3 & \\
\hline Management Review & Not listed & 2 & \\
\hline Journal of Business Ethics & 1.60 & 2 & \\
\hline Academy of Management Journal & 10.78 & 2 & \\
\hline Journal of Organizational Behavior & 4.41 & 1 & \\
\hline Ethnic and Racial Studies & 1.92 & 1 & \\
\hline Personnel Review & 1.17 & 1 & \\
\hline $\begin{array}{l}\text { International Journal of Organizational } \\
\text { Analysis }\end{array}$ & Not listed & 1 & \\
\hline $\begin{array}{l}\text { International Journal of Cross Cultural } \\
\text { Management }\end{array}$ & Not listed & 1 & \\
\hline $\begin{array}{l}\text { International Journal of Business and } \\
\text { Management }\end{array}$ & Not listed & 1 & \\
\hline Public Policy and Administration & Not listed & 1 & \\
\hline University of Auckland Business Review & Not listed & 1 & \\
\hline Industrial and Commercial Training & Not listed & 1 & \\
\hline European Management Review & Not listed & 1 & \\
\hline
\end{tabular}

Krippendorff (1980), a category consists of several pieces of content that share a commonality. By using frequency analysis, the categories have been evaluated according to the most frequently emerging characteristics. 
In a second step, the results of the frequency analysis were refined by a further systematic analysis of the whole content of the database described above in order to develop powerful and distinct criteria out of the identified categories. The results section explicates how this enabled us to clearly distinguish between the three terms.

\section{Results}

The final criteria list has been divided into four different aspects (see Table 4): individual level (criteria concerning the expatriate/migrant himself, e.g. initiative to go abroad), organizational level (criteria concerning the organization, e.g. decision of employment), political/legal level (criteria concerning state or political and legal facilities, e.g. visa status) and finally, criteria with respect to mobility in general (e.g. destination country).

Results of the qualitative content analysis indicate first that there is no consistency in the literature regarding how each of the three individual terms is defined. Taking the term migrant as an example, there are definitions that indicate migrants stay permanently in the immigration country (Massey and Bartley 2006), whereas Wiles (2008), for example, states that the term migrant is associated with temporary dwelling of the individual in a foreign country. Second, Table 4 clearly shows that several criteria for demarcation of the terms AE, SIE and migrant are available.

Whereas the length of stay of SIEs in the host country is considered to be not predetermined (Suutari and Brewster 2000), AEs are often expected to stay for a previously predetermined time frame (Peltokorpi and Froese 2009). This also explains why some authors provide a minimum and maximum duration when defining the term AE (e.g. Collings, Scullion and Morley 2007). This does not apply for the other two groups. In addition, in most cases SIEs are not expected to repatriate (Crowley-Henry 2007), while AEs are likely to repatriate to their home country (Huang, Chi and Lawler 2005).

Regarding the 'initiative' criterion, the term SIE is indicative of a more active individual who chooses to leave (Harrison, Shaffer and Bhaskar-Shrinivas 2004) and initiates the expatriation himself (Myers and Pringle 2005), whereas for AEs the transfer is often initiated by the company (Peltokorpi and Froese 2009). Differences concerning initiative are also reflected by the 'motive' criterion for expatriation. While SIEs seem to expatriate due to personal motives such as self-development, AEs primarily leave in order to accomplish a job- or organizational-related goal (Peltokorpi 2008). Hence, AEs get support from their organizations (Meyskens, von Glinow, Werther and Clarke 2009) such as training prior to the departure (Howe-Walsh and Schyns 2010), whereas SIEs are not sponsored by a company (Carr, Inkson and Thorn 2005). Therefore, self-initiated expatriation rather often, but not always, implies a movement across different organizations (Inkson, Arthur, Pringle and Barry 1997). Contrary to that, assigned expatriates move within the boundaries of one organization (Baruch and Altman 2002). Following this line of thought, definitions of the term AE often refer to employees (Caligiuri 2000) or managers (Tharenou and Harvey 2006), whereas SIEs describe individuals who seek employment (e.g. Carr et al. 2005), implying an independent movement. Consequently, AEs regard their foreign assignment as part of their organizational career (Siljanen and La"msa“ 2009) unlike SIEs who often follow an individualized career path (Carr et al. 2005).

For migrants, in contrast to AEs and SIEs, the movement across national borders rather than organizational boundaries is the primary focus (Milewski and Hamel 2010). The main motives for migration are settlement in the new country (Waldinger 2008) and improvement of individual economic conditions (Tharmaseelan, Inkson and Carr 2010). The literature on migrants also acknowledges that there are several consequences for the 
Table 4. Criteria list for the demarcation of the terms migrant, assigned expatriate and self-initiated expatriate.

\begin{tabular}{|c|c|c|c|c|}
\hline \multirow[b]{2}{*}{ Criteria } & \multirow{2}{*}{$\begin{array}{l}\text { Distinct for } \\
\text { demarcation } \\
\end{array}$} & \multicolumn{3}{|c|}{ Implications } \\
\hline & & $\operatorname{SIE}(\mathrm{N}=88)$ & $\mathrm{AE}(\mathrm{N}=74)$ & Migrant $(\mathrm{N}=84)$ \\
\hline \multicolumn{5}{|l|}{ Individual level } \\
\hline Duration & Ambiguous & $\begin{array}{l}\text { Long-term, temporary to permanent, } \\
\text { rather not predetermined } \\
2,7,11,37,54,68,73,76,113,114,119,132\end{array}$ & $\begin{array}{l}\text { Long-term, temporary to permanent, } \\
\text { rather predetermined period } 17,29,38,54,56, \\
73,79,80,84,85,89,91,104,107,115,117,121,123,126,128\end{array}$ & $\begin{array}{l}\text { Long-term, temporary } \\
\text { to permanent, repeated } \\
\text { periods s,28,65,69,82,87,96, } \\
105,109,129,131\end{array}$ \\
\hline Initiative (5) & Distinct & $\begin{array}{l}\text { Individually initiated } \\
2,3,7,9,13,23,35-37,43,55,58,60,73,76,84,85, \\
100,102,104,110,113,119,132\end{array}$ & $\begin{array}{l}\text { Organizationally } 17,18,33,34,38,64,66,73,80,84,85, \\
89,91,93,99,104,111,115,121,128 \\
\text { or individually and organizationally } \\
\text { initiated }\end{array}$ & $\begin{array}{l}\text { Individually initiated }{ }^{7,67} \\
\text { or politically initiated }{ }^{4,40}\end{array}$ \\
\hline Motives & Ambiguous & $\begin{array}{l}\text { Personal and professional motives with } \\
\text { a dominance of personal goals } 9,13,35-37 \\
43,44,54,55,59,60,76,84,85,102-104,107,114,119\end{array}$ & $\begin{array}{l}\text { Personal and professional motives with a } \\
\text { dominance of organization-related goals } \\
10,18,20,23,33,34,38,64,66,80,84,85,99,104,107,111 \\
115,123,127\end{array}$ & $\begin{array}{l}\text { Different reasons, rather } \\
\text { economic or politicals, } \\
28,31,46,50,55,62,69,71,82,88 \\
105,116,124,125,131\end{array}$ \\
\hline Repatriation & Ambiguous & $\begin{array}{l}\text { Either intention to repatriate or } \\
\text { not } 2,13,55,119\end{array}$ & $\begin{array}{l}\text { Rather intention to repatriate, repatriation } \\
\text { agreement } 14,25,49,56,63,66,73\end{array}$ & $\begin{array}{l}\text { Either intention to } \\
\text { repatriate or not }{ }^{2,5,19,48,86}\end{array}$ \\
\hline $\begin{array}{l}\text { Emotional attachment to } \\
\text { home/host country }\end{array}$ & Ambiguous & Home and/or host country ${ }^{12}$ & Home and/or host country ${ }^{16}$ & $\begin{array}{l}\text { Home and/or host } \\
\text { country8,48,105 }\end{array}$ \\
\hline Relocation of family & Ambiguous & & $\begin{array}{l}\text { Either relocation of family or not } \\
29,34,41,49,63,73,108\end{array}$ & \\
\hline $\begin{array}{l}\text { Consequences for } \\
\text { individual }\end{array}$ & Ambiguous & & & $\begin{array}{l}\text { In tendency social ties } \\
\text { in several countries } \\
105,120,125\end{array}$ \\
\hline \multicolumn{5}{|l|}{ Organizational level } \\
\hline Executing work abroad (3) & Distinct & $\begin{array}{l}\text { Employed individuals 1,6,9,13,16,20,23,32, } \\
35,43,55,57,72,73,102-104,113,114,132\end{array}$ & $\begin{array}{l}\text { Employed individuals } 10,17,18,20,27,33,34,49,54, \\
63,66,79,80,99,104,111,115,126-128\end{array}$ & $\begin{array}{l}\text { Individuals, occupation } \\
\text { not mandatorily } \\
\text { necessary40,70,81,90,106,130 }\end{array}$ \\
\hline Legality of employment (4) & $\begin{array}{l}\text { Distinct for } \\
\text { illegal workers }\end{array}$ & $\begin{array}{l}\text { Legal, mostly dependent employment }{ }^{13,43} \text {; } \\
\text { sometimes independent work activities }\end{array}$ & $\begin{array}{l}\text { Legal, mostly dependent employment }{ }^{84} \text {; } \\
\text { sometimes independent work activities }\end{array}$ & $\begin{array}{l}\text { Working }{ }^{106} \\
\text { or not working; legal or } \\
\text { illegal work }\end{array}$ \\
\hline
\end{tabular}


Table 4 - continued

\begin{tabular}{|c|c|c|c|c|}
\hline \multirow[b]{2}{*}{ Criteria } & \multirow{2}{*}{$\begin{array}{l}\text { Distinct for } \\
\text { demarcation }\end{array}$} & \multicolumn{3}{|c|}{ Implications } \\
\hline & & $\operatorname{SIE}(\mathrm{N}=88)$ & $\mathrm{AE}(\mathrm{N}=74)$ & Migrant $(\mathrm{N}=84)$ \\
\hline Organizational support & Ambiguous & No or little support from employer ${ }^{4,9,13,36}$ & High support from home and host & Depends, all scenarios \\
\hline Career & Ambiguous & $\begin{array}{l}43,44,55,61,72,77,84,85,92,94,95,100-103,110,112 \\
\text { Self-managed career } 1,6,13,85,101-104,110\end{array}$ & $\begin{array}{l}\text { organization } 20,54,73,84,85,104 \\
\text { Organizational career }\end{array}$ & $\begin{array}{l}\text { possible } \\
\text { Not necessarily career } \\
\text { related }^{132}\end{array}$ \\
\hline Contract partner (6) & Distinct & $\begin{array}{l}\text { New work contract partner }{ }^{12,13,32,35} \text {, } \\
43,55,84,85,93,102,103,110\end{array}$ & Current work contract partner ${ }^{97}$ & $\begin{array}{l}\text { Not mandatorily } \\
\text { necessary, all scenarios } \\
\text { possible }^{130}\end{array}$ \\
\hline $\begin{array}{l}\text { Political/legal level } \\
\text { Citizenship }\end{array}$ & Ambiguous & Maybe or not ${ }^{4}$ & $\begin{array}{l}\text { Not aspired, but might change } \\
\text { abroad } 21,45\end{array}$ & $\begin{array}{l}\text { May be citizen or not } \\
15,22,26,28,42,51,69,70,74,75 \\
81,118\end{array}$ \\
\hline Visa status & Ambiguous & $\begin{array}{l}\text { Yes, work permit; status depends on } \\
\text { immigration policies }{ }^{4}\end{array}$ & $\begin{array}{l}\text { Yes, work permit; status depends } \\
\text { on immigration policies }{ }^{83}\end{array}$ & $\begin{array}{l}\text { Either visa or } \text { not }^{28,40,48} \\
69,82,88,122\end{array}$ \\
\hline Assessment (taxation) & Ambiguous & Rather in host country (local contract) ${ }^{39}$ & $\begin{array}{l}\text { Rather in home country (expatriate } \\
\text { contract) }\end{array}$ & $\begin{array}{l}\text { Rather in host country } \\
\text { (local contract) or no } \\
\text { taxes (no contract) })^{98}\end{array}$ \\
\hline $\begin{array}{l}\text { Movement in general } \\
\text { Internal versus external } \\
\text { organizational mobility (7) }\end{array}$ & Distinct & $\begin{array}{l}\text { Crossing national and organizational } \\
\text { boundaries2,3,6,7,9,13,23,32,37,43,55,57,60,76, } \\
77,84,85,100,104,113,119\end{array}$ & $\begin{array}{l}\text { Crossing national but not } \\
\text { organizational boundaries } \\
53,104,107,115\end{array}$ & $\begin{array}{l}\text { Crossing national } \\
\text { boundaries2,8,19,24,26,28, } \\
30,31,46,47,55,62,74,78,96,105, \\
109,125,131\end{array}$ \\
\hline Origin & Ambiguous & & $\begin{array}{l}\text { Starting from a company }{ }^{17,20,27,53} \text {, } \\
54,80,85,89,104,107,117\end{array}$ & $\begin{array}{l}\text { Starting from a by } \\
\text { tendency developing } \\
\text { country } 3,2,8,28,68,124,131\end{array}$ \\
\hline Destination & Ambiguous & $\begin{array}{l}\text { Going to foreign country }{ }^{2,7,9,13,32,37,43} \text {, } \\
54,55,76,85,92,93,100-103,113,114,119\end{array}$ & $\begin{array}{l}\text { Going to foreign subsidiary } 10,17,18,20,29, \\
33,34,38,53,56,66,73,79,80,84,85,89,91,93,99, \\
104,107,111,115,123,127\end{array}$ & $\begin{array}{l}\text { Going to foreign country } \\
2,5,8,28,46,82,87,96,116\end{array}$ \\
\hline
\end{tabular}

Notes: The superscript numbers refer to the numbered references; the numbers in parentheses refer to the distinct criteria depicted in Figure 1. 
individual that result from the geographical relocation, such as relationships that span across borders (Glick-Schiller 2003). This circumstance is not considered in the definitions of expatriates. Furthermore, migrants are characterized by political and legal characteristics such as country of birth (Massey and Bartley 2006) and country of residence (Parreñas 2010) as well as visa status (Preibisch 2010). Strikingly, the organization-related criteria from the expatriate literature, for instance, organizational support, do not appear in the migration literature. Hence, the concept of expatriation is tailored to the organizational context of working abroad, whereas the concept of migration is tailored to the general context of crossing geographical borders.

Below, we build on the qualitative content analysis to outline the differentiated definitions of the terms migrant, assigned expatriate and self-initiated expatriate. We applied only criteria which the literature has identified as clear-cut and unambiguous (distinct). A criterion was classified as distinct if it distinguishes at least two of the three groups. In Table 4 an overview is given in Column 2, outlining which criteria are suitable for such a demarcation ('distinct') and which criteria are not precise enough ('ambiguous'). By this means we found five distinct criteria which were further underpinned by theoretical models such as the Rubicon model of action phases (Heckhausen and Gollwitzer 1987). Due to the fact that the analyzed literature did not generate any distinct criteria for the differentiation between migrants and non-migrants, two further distinct criteria have been derived from already existing official definitions (e.g. United Nations (1998) and OECD model tax convention (2012) outlined below). The following discussion is solely built on these seven distinct criteria (see also Figure 1).

\section{Distinguishing migrants from non-migrants}

Figure 1 depicts the various considerations to distinguish migrants from non-migrants, migrants from expatriates and in turn, SIEs from AEs.

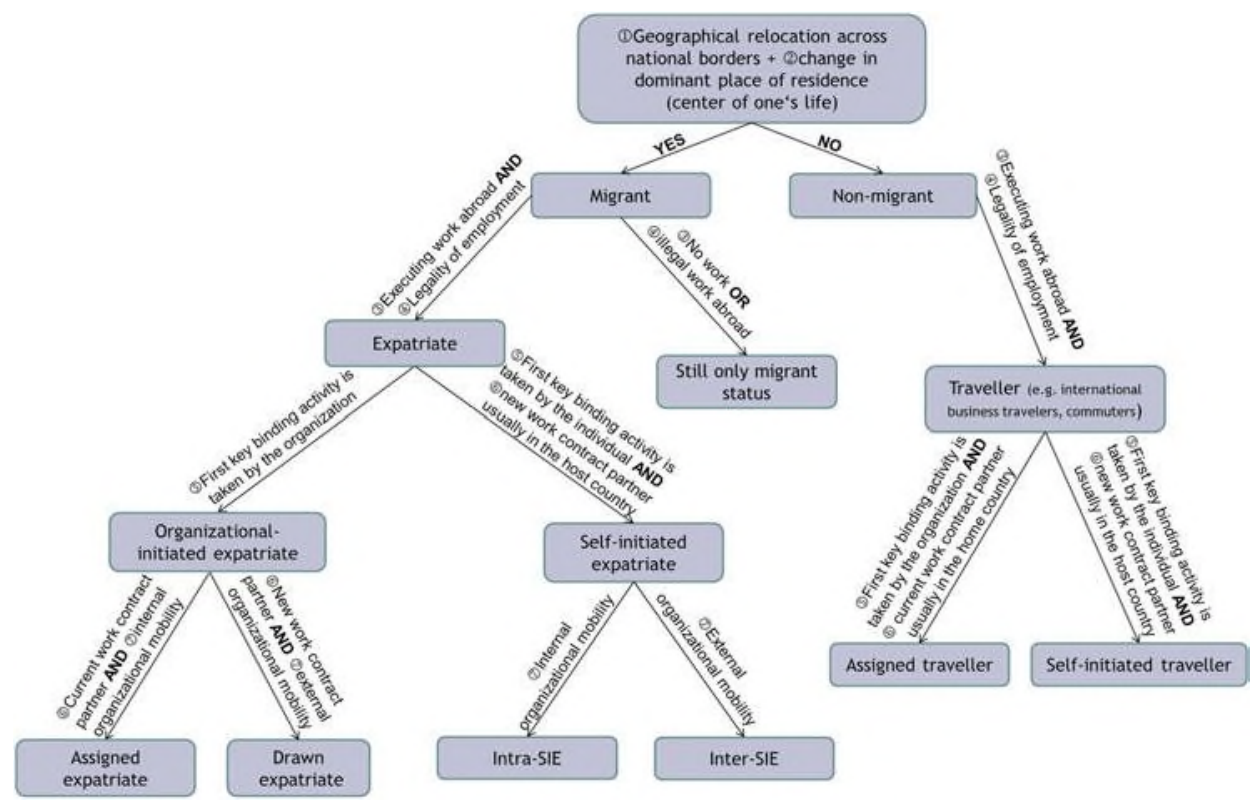

Figure 1. Decision tree. 
The following Arabic numerals relate directly to the seven criteria indicated in Figure 1. The first two criteria to distinguish migrants from non-migrants are (1) geographical relocation across national borders and (2) change in dominant place of residence. A person is considered as a migrant if he moves from one geographical point to another geographical point (Agozino 2000), crossing national borders (Boyle et al. 1998) and changes his dominant place of residence which is the center of a person's life (United Nations 1998). Both criteria (1 and 2) must be considered to distinguish between migrants and non-migrants. According to the OECD model tax convention (Art. 4(2)), the dominant place of residence can be defined in a four-step process called the 'tiebreaker rule' (Stuart 2010). If the first criterion does not result in a plain demarcation of a person's dominant place of residence, the next criterion has to be considered. If the second criterion does not lead to a clear result, the third or fourth criterion should be used. First, an individual's center of life is usually (I) where the person's family (domestic partner or spouse, children) live. If this does not lead to a clear result then (II) the person's economic interests are considered (e.g. administration of property). Then, (III) the person's habitual abode is of interest, which is usually assumed to be where the person spends more than 183 days of the year. The last criterion is (IV) the person's nationality (e.g. as indicated in the passport) (Stuart 2010).

\section{Classifying migrants and expatriates}

In addition to the two criteria demarcating migrants from non-migrants, two further criteria serve to identify expatriates as a subgroup of migrants. Both criteria (3 and 4) are necessary to clearly demarcate the two terms. The third criterion is (3) 'executing work abroad' (see Table 4 and Figure 1). First, a person can only be named AE or SIE if the person executes his work abroad. Therefore, individuals who move to a foreign country, i.e. crossing national borders and changing their dominant place of residence without taking up work (such as dependents of expatriates, under-age children, non-working partners or non-employed foreign students) can be categorized as migrants, but not as expatriates. The fourth criterion to demarcate between migrant and expatriate is (4) 'legality of employment' (see Table 4 and Figure 1). All the evaluated literature indicated that to be considered as an expatriate a person must have legal employment (e.g. Suutari and Brewster 2000; Biemann and Andresen 2010; Doherty et al. 2011). Hence, pursuing independent, legal work (e.g. as self-employed and/or owners of organizations) also qualifies individuals as expatriates (see Inkson et al. 1997; Stone and Stubbs 2007). However, individuals working illegally in a foreign country are excluded from the expatriate category.

Summing up, our analysis of the literature shows that the term migrant is an umbrella term for all expatriates but that some migrants - those who do not work or who are illegally working - are not expatriates (Figure 1). Previous research, however, claimed that migrants and expatriates are two exclusive groups (Al Ariss 2010; Baruch et al. 2010).

\section{Distinguishing SIEs from AEs}

Three additional criteria, (5) 'initiator of key binding activity' (whether the initiative comes from the individual or the organization), (6) 'change of work contract partner' and

(7) 'internal versus external organizational mobility' sufficiently differentiate between the terms AE and SIE. It is important to mention that these three criteria are necessary to distinguish AEs from SIEs. 
When defining initiation in terms of a general, non-binding articulated interest in a foreign work experience, both types of expatriation can be individually and organizationally initiated (Harris and Brewster 1999; Thorn 2009). In the following, we focus on the initiation of a key binding activity. Since work-related stays abroad can be regarded as goal-oriented behavior (Spieß and Wittmann 1999), the Rubicon model of action phases (see Figure 2; Heckhausen and Gollwitzer 1987; Gollwitzer 1991; Heckhausen and Heckhausen 2010) helps to explain the difference between assigned expatriates and self-initiated expatriates in terms of the criterion 'initiator of key binding activity' (see Figure 1).

The model starts with the pre-decisional or deliberating phase, where alternatives are evaluated, preferences are built and motivation is formed. This means a person has a diffuse idea to work abroad and evaluates options such as assigned or SIE.

This process leads to what Heckhausen (1989) describes metaphorically as the crossing of the Rubicon, i.e. the development of a goal intention. This means that an employee develops the concrete intention to go abroad as, for example, a self-initiated expatriate, i.e. to apply for a job abroad on his own. The final decision is influenced by valence and expectancy parameters (Vroom 1964). Since both AEs and SIEs decide for themselves to work in a foreign country (i.e. build their own goal intention), they do not differ at this point of the model.

The post-decisional phase can be subdivided into a pre-actional, an actional and a post-actional phase.

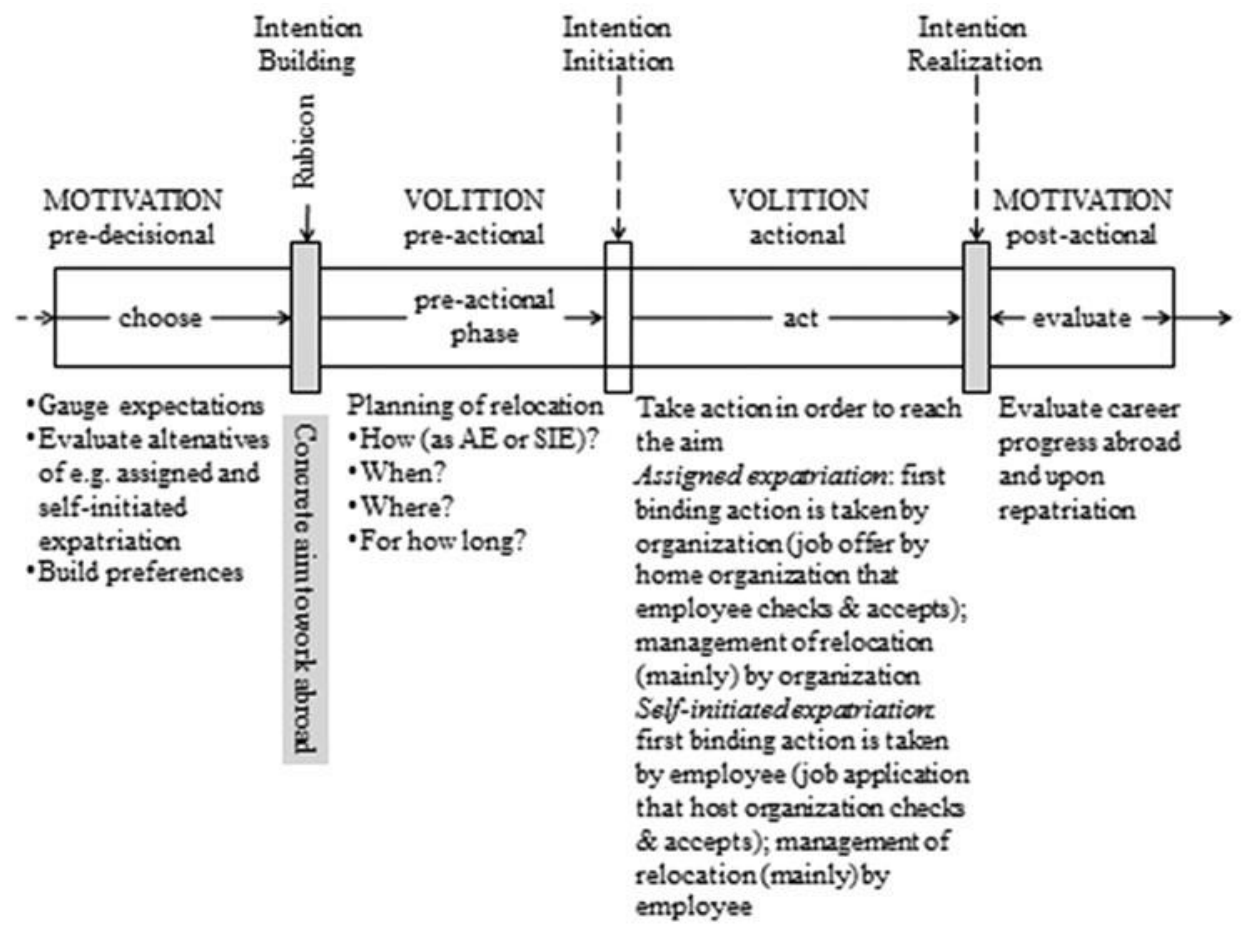

Figure 2. Rubicon model of action phases (following Heckhausen and Gollwitzer 1987; Heckhausen and Heckhausen 2010). 
In the pre-actional or planning phase, a definitive action plan is formed and intermediate goals are developed. In the case of a person who decides to go abroad as an SIE, intermediate goals would include the search for international job offers and the preparation of a palpable job application. A person who is eager to be assigned abroad might mention his interest to his superior. It is important to mention that no concrete action in terms of applying for a job abroad, in the case of SIEs, is taken at this point of the model; the planning is still without any engagement. This phase solely contains the planning of further action steps that might finally be realized in the action phase. Moreover, individuals protect the chosen intention (e.g. going abroad as SIE) from competing intentions.

In the following action phase, differences between AEs and SIEs become apparent. In the case of $\mathrm{AE}$, an employee receives a formalized job offer for a position in a foreign subsidiary by his current work contract partner. The employee needs to check and accept or reject this offer. Thus, the first key binding activity is taken by the organization, i.e. the current work contract partner. In the case of SIE, by contrast, the employee himself applies for a foreign job. Thus, the first key binding activity is taken by the individual. The new work contract partner abroad, either in the same organization (Intra-SIEs) or in a new organization (Inter-SIEs), checks the application and acts on it. Both alternatives lead to a realization of the goal intention, i.e. the conclusion of a contract, followed by the management and implementation of the specific assignment (mainly) by the current work contract partner. Since SIEs might face more obstacles in the action phase than assigned expatriates (e.g. in terms of financial challenges, resulting in negative emotions such as fear or uncertainty), these individuals need a stronger volition, such as selfregulation strategies and discipline, in order to reach their goal to work in a foreign country (Doherty and Dickmann 2013).

Finally, the post-actional phase is when an action is completed. Outcomes of actions, e.g. in terms of career progress while working abroad and/or after repatriation to the home country, are evaluated by the individual. Success or failure judgments are often accompanied by emotions; positive (e.g. pride) or negative (e.g. anger), reinforcing or hampering similar action in the future (Weiner 1985).

The remaining two criteria, 'change of work contract partner' and 'internal versus external organizational mobility', depend on who takes the final decision to employ the expatriate abroad. For AEs this decision is usually taken in the home country. In contrast, the final decision to employ SIEs is made by a new work contract partner, usually in the host country. This new work contract partner is either the same organization (Intra-SIE) internal organizational mobility to a foreign subsidiary - or a new organization (InterSIE).

\section{Distinguishing migrants and expatriates from travellers}

A person who moves to another geographical point and crosses borders without changing his dominant place of residence (i.e. center of his life) is not considered to be a migrant (see Figure 1). For instance, 'International Business Travellers' (IBTs) can be excluded from the migrant category as IBTs frequently move between different countries without changing their dominant place of residence, e.g. the family or partner remains in the home country (Collings et al. 2007; Welch, Welch and Worm 2007). IBTs do not belong to the category of expatriates in the narrower sense.

As the decision of employment is made by the home organization and the first formalized action (offering an IBT a contract) is taken by the organization, an IBT 
belongs to the category of assigned travellers. In addition, cross-border commuters regularly move between different geographical points, crossing national borders, in order to get to their place of employment without changing their place of dominant residence (Knowles and Matthiesen 2009). Summing up, all international workers who are located on the right side of the decision tree (see Figure 1) do not belong to the umbrella category migrant or expatriate. We denominate these groups such as IBTs and commuters as 'travelers'.

\section{Discussion: four types of AEs and SIEs}

In the literature and research, several forms of expatriates are distinguished such as assigned and self-initiated expatriates. However, the categorization described above is limited to the distinctions made so far in the literature. Additional concepts may be missing as they are either not (yet) operationalized in the literature or have not been included in the sample of articles. One group to be mentioned that has received less attention in research so far are self-employed expatriates who belong to the group of SIEs. This limitation allows us to move beyond the normal 'discourse' on migration and expatriation just as Bartlett and Ghoshal's definition of a global, international or transnational company is much more precise than the normal discourse in newspapers, magazines and many academic articles (Bartlett and Ghoshal 1989).

Based on the analysis of existing definitions and demarcations of terms, research gaps become obvious. Figure 3 provides a typology of four different types of international employees: Inter-SIEs, Intra-SIEs, AEs and a new category named 'drawn expatriates' (DEs).

We have argued that, in the case of SIEs, the initiative always comes from the individual and that the decision to employ an SIE is always made by a new work contract partner. In contrast, an $\mathrm{AE}$ is initiated by the current organization that takes the first key binding action by offering an employment contract for a temporary work assignment abroad. This process tends to uphold the legal anchor to the current work contract partner in the home country.

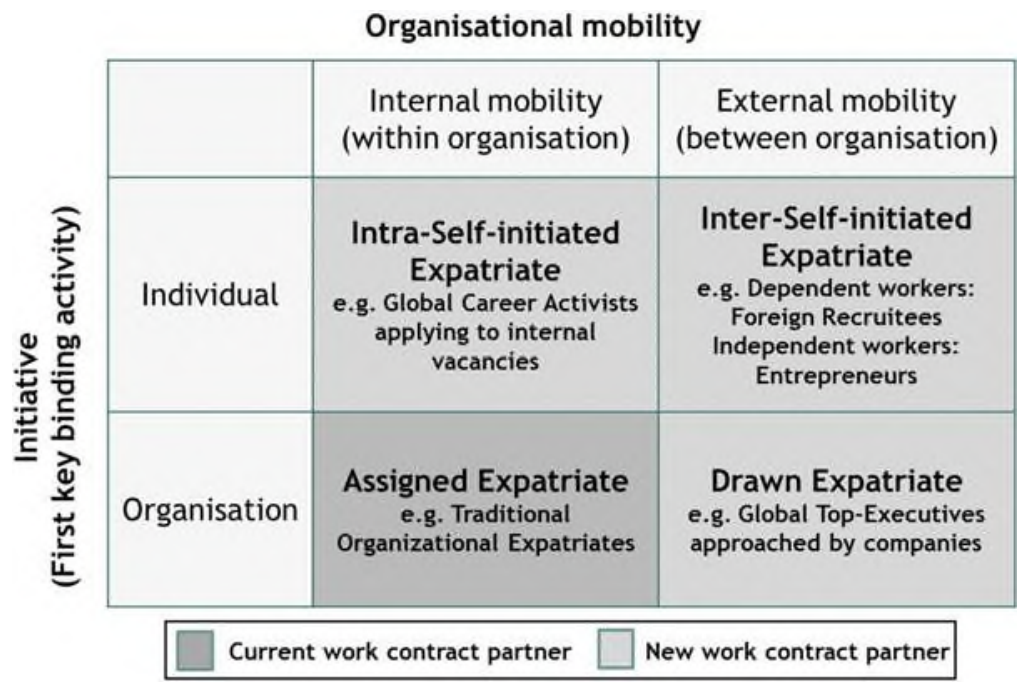

Figure 3. Typology of internationally mobile employees. 
From this analysis, it becomes obvious that an additional group of mobile employees needs to be distinguished: individuals who are offered a job from an organization outside of their current country (6) (new work contract partner), e.g. based on their networks and/ or reputation, without having applied for the position in question. An example of a DE could be a top executive being approached by a prospective employer who outlines a job offer. The person in question would clearly be mobile between organizations (7) (external organizational mobility) and change country and work contract partner. Both criteria (6 and 7) are necessary to differentiate DEs from the other three forms of international mobile employees. Moreover, considering the Heckhausen model of action phases (see Figure 2), the initiative in terms of a first key binding action is taken by the new organization offering an employment contract. Hence, in contrast to AEs, the final decision to employ the expatriate is made by a new work contract partner in a foreign country. It is obvious that research on DEs is hitherto underdeveloped.

\section{Conclusions}

Overall, our research identified that seven demarcation criteria are sufficient for plain differentiation between the terms AE, DE, SIE and migrant, while the other discussed criteria found in the literature do not provide a satisfactory distinction (e.g. organizational support):

(1) Move from one geographical point to another via crossing national borders (yes/ no)

(2) Change of dominant place of residence which is the center of a person's life (yes/ no)

(3) Execution of work in the form of dependent or independent employment (yes/no)

(4) Legality of employment (legal vs illegal)

(5) Initiator of key binding activity in job search (organization vs individual)

(6) Work contract partner (current vs new)

(7) Organizational mobility (internal vs external)

Based on these criteria, the terms AE and SIE are defined as follows:

An expatriate is an individual who moves to another country while changing the dominant place of residence and executes legal work abroad. As such, the expatriate has migrant status.

In the case of SIEs, the first key binding activity to move internationally is solely made by the individual who initiates the expatriation. The legal decision of employment is made by a new work contract partner - either a foreign unit of the organization where the SIE is currently employed (Intra-SIEs) or a new organization abroad (Inter-SIEs).

In the case of AEs, the first key binding activity to expatriate is taken by the organization and the legal decision of employment is made by the current work contract partner, usually in the home country. Organizational mobility of AEs is internal.

In the rare case of DEs, the host country organization (new work contract partner) approaches the individual and offers a legal employment contract leading to external organizational mobility. 
Our findings have crucial theoretical and operational implications for future expatriation research. First, our distinction allows the creation of a much more precise and nuanced categorization of internationally mobile persons. It helps to distinguish whether individuals are migrants or not and clearly demonstrates that all expatriates are included in the group of migrants. In so doing we have been able to challenge currently available models on the demarcation of the terms SIE, AE and migrant (Al Ariss 2010; Baruch et al. 2013).

Second and related, our definition allows an easier categorization and measurement than was possible before. For instance, Al Ariss (2010) uses criteria such as geographical origin and destination of the international mobility, the period of stay abroad and the forced or chosen nature of the international move to distinguish migration from expatriation. Many of these or other criteria, such as the mindset of people whether they want to return to their country-of-origin, are open to different interpretation and the setting of different thresholds (e.g. are people who have been employed in a foreign country for 10 years expatriates or migrants in their frameworks?). Using clear distinctions, such as the 'tie-breaker rule' (Stuart 2010) outlined above, to distinguish migrants from non-migrants and the criteria of legal employment to distinguish expatriates from non-expatriates ('mere' migrants) allows easier and high-quality categorizations.

Suutari and Brewster (2000) were one of the first who recognized that SIEs 'are not a homogeneous group' (p. 430). A third contribution of this article is that by using our refined insights regarding initiative, researchers are able to more clearly define if their sample consists of AEs or SIEs. We distinguish between Intra-SIEs and Inter-SIEs. This distinction is relatively neglected in research design so far with the consequence that often all company-sponsored expatriates are treated as AEs while they might be IntraSIEs (e.g. Dickmann, Doherty, Mills and Brewster 2008). Given the differences that begin to emerge in relation to the motivations and career impact of AEs versus SIEs (Doherty et al. 2011), distinguishing clearly between the two forms will be crucial for future research. Bearing this important distinction in mind could serve to explain existing heterogeneous results on expatriates and to facilitate interpretation of future research results.

A fourth contribution is the identification of a neglected category of expatriates. DEs - e.g. board members of global firms who are offered jobs based on their networks and track-record/reputation rather than having to apply for specific positions - have not, to our knowledge, been identified or researched in the literature. In addition, we lack research insights on difficult-to-access populations such as Inter-SIEs pursuing independent work - e.g. foreign entrepreneurs.

These insights, especially if these were to be taken up by researchers, can give rise to a range of management contributions. In their studies, using a self-reported measure of whether expatriates see themselves as self-initiated or assigned, Biemann and Andresen (2010) as well as Doherty et al. (2011) outline distinct motivators and career patterns of SIEs and AEs. Future research that makes a clear distinction between these types of expatriates may not only be a better basis to integrate the findings, but it may also give better insights for organizations developing HR policies aimed at foreign workers. For instance, corporate branding strategies, recruitment targets, selection criteria and onboarding activities may be geared to the different populations (Howe-Walsh and Schyns 2010; Andresen and Biemann 2013; Doherty and Dickmann 2013). Dickmann and Baruch (2011) argue that superior information on SIEs will allow companies to develop more sophisticated and targeted talent, performance, career and retention management. Given that our distinctions should enable more nuanced research findings, further managerial contributions should emerge. 


\section{Limitations of the study}

Some limitations restrict the validity of our research results. First, the database for AEs and migrants was constrained to 10 sociological, business and psychological journals, considering all publications in the period from 2005 to 2010. Especially, the term migrant has a long tradition in the sociological field of research (Millar and Salt 2007), so our database does not include older definitions of the term migrant and other forms of scientific publications such as monographs. However, the primary goal of this study was to outline the current state of research concerning the definition of the terms AE, SIE and migrant. A second limitation is caused by the fact that many definitions did not contain all of the defined demarcation criteria, resulting in a high level of missing values and low frequencies of characteristics. Still, this is also a result, eventually revealing that a special criterion (e.g. visa status) is not important to define the term (e.g. SIE or AE).

A further limitation may be our choice of using clear-cut and often legal categories to distinguish the different forms of living abroad (migration) and working abroad (SIEs, AEs or DEs). This does not take account of psychological processes and time implications. Development over time is difficult to capture and there are still some thorny questions to clarify. Imagine individuals who were self-initiated students on a degree course abroad and during the study period took up an internship in a holding company where another unit then offered them a job on completion of the degree without a formal application being made. These transitions (first being a migrant, then a self-initiated expatriate moving to be a DE) are difficult to capture but we believe that our framework allows for greater clarity. It does mean, however, that individual careerists can change their legal status. The psychological developments that these students (or any other expatriates) go through and their career patterns working abroad are important to research, but are not part of our categorization mechanism. The reasons are linked to the parsimony of criteria and our strive to use clear, unambiguous categorization criteria.

Even though our categorization is likely to bring more clarity to the international mobility area, we are aware that our expatriate types encompass many different workers. AEs, DEs, Intra-SIEs and Inter-SIEs can pursue a large range of activities (university professors, UN peacekeepers, agricultural laborers). More work may be undertaken to refine these categories even further. We are aware that our framework might not be exhaustive; meaning that in practice there might be other types of international mobility which have not yet been identified. We perceive this framework to be a model that is flexible enough for adaptation in the future. For instance, we have identified 'DEs' in the research process and integrated them into the existing framework.

We also acknowledge a discourse limitation. Much of the popular literature seems to distinguish migrants from expatriates while our definition stipulates that all expatriates are migrants. This is akin to the Bartlett and Ghoshal (1989) typology of multinational enterprises (MNEs) clearly defining global as highly standardized MNEs while popular discourse uses global in the sense of firms operating in many countries. While it might be hard to overcome the preconceptions of some readers, our definitions should add more clarity and nuance to the understanding of non-migrants, migrants and within these AEs, DEs, Intra-SIEs and Inter-SIEs.

\section{Implications for further research}

Future research should provide empirical proof for our demarcation model and test whether the different subgroups can be plainly distinguished by the identified criteria. 
Besides, future research could build on our study to try to find further differences between AEs and SIEs. For instance, further research on the 'motive' criterion for going abroad is necessary as most of the studies do not reveal major differences so far (Doherty et al. 2011). An important area of research that could serve to sufficiently demarcate the above-mentioned terms is the field of tax law, particularly whether the assessment takes place in the home or host country (Endres, Spengel, Elschner and Schmidt 2005). So far insufficient research has been conducted on this issue (Egner 2012).

Currently, many nations define the term migrant differently. Due to this inconsistency, a person might have migrant status in one country but not in another (e.g. the German definition of immigrants is based on nationality whereas in the Netherlands immigrant status depends on the country of birth of the individual and his parents; Euwals, Dagevos, Gijsberts and Roodenburg 2010). The criteria presented here could serve as a basis for a classification of the different samples found in research studies, in order to determine what kind of subgroups of international movers were included in the migrant category and to better understand and interpret the results found.

Note

1. For ease of reading we will use only the male form in the text below.

\section{References}

\section{The superscript numbers refer to Table 4}

Agozino, B. (2000), Theoretical and Methodological Issues in Migration Research: Interdisciplinary, Intergenerational and International Perspectives, Aldershot Hants: Ashgate.

${ }^{1}$ Agullo, B., and Egawa, M. (2009), 'International Careers of Indian Workers in Tokyo: Examination and Future Directions,' Career Development International, 14, 148 - 168.

${ }^{2}$ Al Ariss, A. (2010), 'Modes of Engagement: Migration, Self-Initiated Expatriation and Career Development,' Career Development International, 15, 338 - 358.

${ }^{3} \mathrm{Al}$ Ariss, A., and Ozbilgin, M. (2010), 'Understanding Self-Initiated Expatriates: Career Experiences of Lebanese Self-Initiated Expatriates,' Thunderbird International Business Review, 54, $275-285$.

${ }^{4}$ Allen, R. (2009), 'Benefit or Burden? Social Capital, Gender, and the Economic Adaptation of Refugees,' International Migration Review, 43, 332 - 365.

Andresen, M., Bergdolt, F., and Margenfeld, J. (2012), 'What Distinguishes Self-Initiated Expatriates From Assigned Expatriates and Migrants? A Literature-Based Definition and Differentiation of Terms,' in Self-Initiated Expatriation: Individual, Organizational, and National Perspectives, eds. M. Andresen, A. Al Ariss, and M. Walther, London: Routledge, pp. $11-41$.

Andresen, M., and Biemann, T. (2013), 'A Taxonomy of Global Careers: Identifying Different Types of International Managers,' International Journal of Human Resource Management, 21, $533-557$.

${ }^{5}$ Arguillas, M.J.B., and Williams, L. (2010), 'The Impact of Parents' Overseas Employment on Educational Outcomes of Filipino Children,' International Migration Review, 44, 300 - 319.

${ }^{6}$ Banai, M., and Harry, W. (2004), 'Boundaryless Global Careers,' International Studies of Management and Organization, 34, $96-120$.

Bartlett, C., and Ghoshal, S. (1989), Managing Across Borders: The Transnational Solution, London: Hutchinson.

Baruch, Y., and Altman, Y. (2002), 'Expatriation and Repatriation in MNCs: A Taxonomy,' Human Resource Management, 41, 239 - 259.

${ }^{7}$ Baruch, Y., Dickmann, M., Altman, Y., and Bournois, F. (2010), 'Exploring International Work: Types and Dimensions of Global Careers,' in Paper Presented at the International Human Resource Management Conference, Birmingham, June 2010. 
Baruch, Y., Dickmann, M., Altman, Y., and Bournois, F. (2013), 'Exploring International Work: Types and Dimensions of Global Careers,' The International Journal of Human Resource Management, Special Issue on International HRM 24, 2369 - 2393.

${ }^{8}$ Beck-Gernsheim, E. (2007), 'Transnational Lives, Transnational Marriages: A Review of the Evidence From Migrant Communities in Europe,' Global Networks, 7, 271 - 288.

${ }^{9}$ Begley, A., Collings, D.G., and Scullion, H. (2008), 'The Cross-Cultural Adjustment Experiences of Self-Initiated Repatriates to the Republic of Ireland Labour Market,' Employee Relations, $30,264-282$.

${ }^{10}$ Benson, G.S., and Pattie, M. (2008), 'Is Expatriation Good for My Career? The Impact of Expatriate Assignments on Perceived and Actual Career Outcomes,' The International Journal of Human Resource Management, 19, 1636 - 1653.

${ }^{11}$ Bhuian, S.N., and Al-Jabri, I.M. (1996), 'Expatriate Turnover Tendencies in Saudi-Arabia: An Empirical Examination,' The International Journal of Organizational Analysis, 4, 393 - 407.

${ }^{12}$ Bhuian, S.N., Al-Shammari, E.S., and Jefri, O.A. (2001), 'Work-Related Attitudes and Job Characteristics of Expatriates in Saudi Arabia,' Thunderbird International Business Review, $43,21-31$.

${ }^{13}$ Biemann, T., and Andresen, M. (2010), 'Self-Initiated Foreign Expatriates Versus Assigned Expatriates: Two Distinct Types of International Careers?' Journal of Managerial Psychology, $25,430-448$.

${ }^{14}$ Black, J.S., Gregersen, H.B., and Mendenhall, M.E. (1992), 'Toward a Theoretical Framework of Repatriation Adjustment,' Journal of International Business Studies, 23, 737 - 760.

${ }^{15}$ Bo' 'hning, R. (2009), 'Getting a Handle on the Migration Rights-Development Nexus,' International Migration Review, 43, $652-670$.

${ }^{16}$ Bonache, J., Brewster, C., and Suutari, V. (2007), 'Preface, Knowledge, International Mobility and Careers,' International Studies of Management and Organization, 37, 3 - 15.

${ }^{17}$ Bonache, J., and Za'rraga-Oberty, C. (2008), 'Determinants of the Success of International Assignees as Knowledge Transferors: A Theoretical Framework,' The International Journal of Human Resource Management, 19, 1, $1-18$.

${ }^{18}$ Bossard, A., and Peterson, R. (2005), 'The Repatriate Experience as Seen by American Expatriates,' Journal of World Business, 40, 9 - 28.

${ }^{19}$ Boswell, C., and Ciobanu, O. (2009), 'Culture, Utility or Social Systems? Explaining the CrossNational Ties of Emigrants From Bors a, Romania,' Ethnic and Racial Studies, 32, 1346 - 1364. Boyle, P., Halfacree, K., and Robinson, V. (1998), Exploring Contemporary Migration, Harlow: Addison Wesley Longman.

${ }^{20}$ Bozionelos, N. (2009), 'Expatriation Outside the Boundaries of the Multinational Corporation: A study With Expatriate Nurses in Saudi Arabia,' Human Resource Management, 48, 111 - 134.

Briscoe, D., Schuler, R.S., and Claus, L. (2009), International Human Resource Management (3rd ed.), London: Routledge.

${ }^{21}$ Brody, E.S., and Binder, J.K. (2010), 'IRS Guidance Adds Body to the Heart Act's New Tax Regime for Expatriates,' Canadian Tax Journal, 58, 447 - 458.

${ }^{22}$ Buzdugan, R., and Halli, S.S. (2009), 'Labor Market Experiences of Canadian Immigrants With Focus on Foreign Education and Experience,' International Migration Review, 43, 366 - 386.

Caligiuri, P.M. (2000), 'Selecting Expatriates for Personality Characteristics: A Moderating Effect of Personality on the Relationship Between Host National Contact and Cross-Cultural Adjustment,' Management International Review, 40, 61 - 80.

${ }^{23}$ Cappellen, T., and Janssens, M. (2008), 'Global Managers' Career Competencies,' Career Development International, 13, $514-537$.

${ }^{24}$ Carling, J. (2008), 'Toward a Demography of Immigrant Communities and Their Transnational Potential,' International Migration Review, 42, 449 - 475.

Carr, S., Inkson, K., and Thorn, K. (2005), 'From Global Careers to Talent Flow: Reinterpreting "Brain Drain",' Journal of World Business, 40, 386 - 398.

${ }^{25}$ Cerdin, J.-L., and Pargneux, M.L. (2009), 'Career and International Assignment Fit: Toward an Integrative Model of Success,' Human Resource Management, 48, 5 - 25.

${ }^{26}$ Chew, K., Leach, M., and Liu, J.M. (2009), 'The Revolving Door to Gold Mountain: How Chinese Immigrants Got Around U.S. Exclusion and Replenished the Chinese American Labor Pool, 1900 - 1910,' International Migration Review, 43, 410 - 430. 
${ }^{27}$ Colakoglu, S., Tarique, I., and Caligiuri, P. (2009), 'Towards a Conceptual Framework for the Relationship Between Subsidiary Staffing Strategy and Subsidiary Performance,' The International Journal of Human Resource Management, 20, 1291 - 1308.

${ }^{28}$ Colic-Peisker, V. (2010), 'Free Floating in the Cosmopolis? Exploring the Identity-Belonging of Transnational Knowledge Workers,' Global Networks, 10, 467 - 488.

${ }^{29}$ Collings, D., Scullion, H., and Morley, M. (2007), 'Changing Patterns of Global Staffing in the Multinational Enterprise: Challenges to the Conventional Expatriate Assignment and Emerging Alternatives,' Journal of World Business, 42, 198 - 213.

${ }^{30}$ Collins, F.L. (2008), 'Bridges to Learning: International Student Mobilities, Education Agencies and Inter-Personal Networks,' Global Networks, 8, $398-417$.

${ }^{31}$ Conway, D., Potter, R.B., and Bernard, G. (2008), 'Dual Citizenship or Dual Identity? Does "Transnationalism" Supplant "Nationalism" Among Returning Trinidadians?' Global Networks, 8, $373-397$.

${ }^{32}$ Crowley-Henry, M. (2007), 'The Protean Career: Exemplified by First World Foreign Residents in Western Europe?' International Studies of Management and Organization, 37, 44 - 64.

David, R.J., and Han, S.-K. (2004), 'A Systematic Assessment of the Empirical Support for Transaction Cost Economics,' Strategic Management Journal, 25, 39 - 58.

${ }^{33}$ De Cieri, H., Fenwick, M., and Hutchings, K. (2005), 'The Challenge of International Human Resource Management: Balancing the Duality of Strategy and Practice,' The International Journal of Human Resource Management, 16, 584 - 598.

Dickmann, M., and Baruch, Y. (2011), Global Careers, Abingdon: Routledge.

Dickmann, M., Doherty, N., Mills, T., and Brewster, C. (2008), 'Why Do They Go? Individual and Corporate Perspectives on the Factors Influencing the Decision to Accept an International Assignment,' International Journal of Human Resource Management, 19, 731 - 751.

${ }^{34}$ Dickmann, M., and Harris, H. (2005), 'Developing Career Capital for Global Careers: The Role of International Assignments,' Journal of World Business, 40, 399 - 408.

${ }^{35}$ Doherty, N. (2013), 'Understanding the Self-Initiated Expatriate: A Review and Directions for Future Research,' International Journal of Management Reviews. doi: 10.1111/ijmr.12005.

Doherty, N., and Dickmann, M. (2013), 'Self-Initiated and Assigned Expatriates: Talent Management and Career Considerations,' in Managing Talent of Self-Initiated Expatriates: A Neglected Source of the Global Talent Flow, eds. V. Vaiman and A. Haslberger, London: Palgrave MacMillan, pp. $234-255$.

${ }^{36}$ Doherty, N., Dickmann, M., and Mills, T. (2011), 'Exploring the Motives of Company-Backed and Self-Initiated Expatriates,' The International Journal of Human Resource Management, 22, $595-611$

Egner, T. (2012), 'Tax and Salary Issues in Self-Initiated Expatriation,' in Self-Initiated Expatriation: Individual, Organizational, and National Perspectives, eds. M. Andresen, A. Al Ariss, and M. Walther, London: Routledge, pp. $143-159$.

${ }^{37}$ Ellis, D.R. (2012), 'Exploring Cultural Dimensions as Predictors of Performance Management Preferences: The Case of Self-Initiating Expatriate New Zealanders in Belgium,' The International Journal of Human Resource Management, 23, 2087 - 2107.

${ }^{38}$ Emmerik, I.H.V., and Euwema, M.C. (2009), 'The International Assignments of Peacekeepers: What Drives Them to Seek Future Expatriation?' Human Resource Management, 48, 135 - 151.

${ }^{39}$ Endres, D., Spengel, C., Elschner, C., and Schmidt, O. (2005), 'The Tax Burden of International Assignments,' Intertax, 33, 409 - 502.

Euwals, R., Dagevos, J., Gijsberts, M., and Roodenburg, H. (2010), 'Citizenship and Labor Market Position: Turkish Immigrants in Germany and the Netherlands,' International Migration Review, 44, 513 - 538.

${ }^{40}$ Fargues, P. (2009), 'Work, Refuge, Transit: An Emerging Pattern of Irregular Immigration South and East of the Mediterranean,' International Migration Review, 43, 544 - 577.

${ }^{41}$ Farndale, E., Scullion, H., and Sparrow, P. (2010), 'The Role of the Corporate HR Function in Global Talent Management,' Journal of World Business, 45, $161-168$.

${ }^{42}$ Feld, S. (2005), 'Labor Force Trends and Immigration in Europe,' International Migration Review, $39,637-662$.

${ }^{43}$ Fitzgerald, C., and Howe-Walsh, L. (2008), 'Self-Initiated Expatriates: An Interpretative Phenomenological Analysis of Professional Female Expatriates,' International Journal of Business and Management, 3, $156-175$. 
${ }^{44}$ Forstenlechner, I. (2010), 'Brain Drain in Developed Countries: Can Governments Do Anything to Bring Expatriates Back?' Public Policy and Administration, 25, 156 - 174.

Freeman, G.P., and Ogelman, N. (1998), 'Homeland Citizenship Policies and the Status of Third

Country $769-788$

${ }^{46}$ Furman, R., Negi, N., Schatz, M.C.S., and Jones, S. (2008), 'Transnational Social Work: Using a Wraparound Model,' Global Networks, 8, 496 - 503.

${ }^{47}$ Gardner, K. (2006), 'The Transnational Work of Kinship and Caring: Bengali-British Marriages in Historical Perspective,' Global Networks, 6, 373 - 387.

Glick-Schiller, N. (2003), 'The Centrality of Ethnography in the Study of Transnational Migration: Seeing the Wetlands Instead of the Swamp,' in American Arrivals, ed. E.N. Foner, Santa Fe, NM: School of American Research Press, pp. 99 - 128.

Gollwitzer, P.M. (1991), Abwa"gen und Planen: Bewusstseinslagen in verschiedenen Handlungsphasen, Go"ttingen: Hogrefe.

${ }^{48}$ Gustafson, P. (2008), 'Transnationalism in Retirement Migration: The Case of North European Retirees in Spain,' Ethnic and Racial Studies, 31, 451 - 475.

${ }^{49}$ Guzzo, R.A., Noonan, K.A., and Elron, E. (1994), 'Expatriate Managers and the Psychological Contract,' Journal of Applied Psychology, 79, 617 - 626.

${ }^{50}$ Haller, W., and Landolt, P. (2005), 'The Transnational Dimensions of Identity Formation: Adult Children of Immigrants in Miami,' Ethnic and Racial Studies, 28, 1182 - 1214.

${ }^{51}$ Hao, L., and Kim, J.J.H. (2009), 'Immigration and the American Obesity Epidemic,' International Migration Review, 43, 237 - 262.

${ }^{52}$ Harris, H., and Brewster, C. (1999), 'The Coffee-Machine System: How International Selection Really Works,' The International Journal of Human Resource Management, 10, 488 - 500.

Harrison, D.A., Shaffer, M.A., and Bhaskar-Shrinivas, P. (2004), 'Going Places: Roads More and Less Traveled in Research on Expatriate Experiences,' Research in Personnel and Human Resources Management, 23, 199 - 247.

${ }^{53}$ Haslberger, A., and Brewster, C. (2009), 'Capital Gains: Expatriate Adjustment and the Psychological Contract in International Careers,' Human Resource Management, 48, 379 - 397.

Heckhausen, H. (1989), Motivation und Handeln, Berlin: Springer.

Heckhausen, H., and Gollwitzer, P.M. (1987), 'Thought Contents and Cognitive Functioning in Motivational Versus Volitional States of Mind,' Motivation and Emotion, 1, $101-120$.

Heckhausen, J., and Heckhausen, H. (2010), Motivation and Action, Cambridge: Cambridge University Press.

${ }^{54}$ Howe-Walsh, L., and Schyns, B. (2010), 'Self-Initiated Expatriation: Implications for HRM,' The International Journal of Human Resource Management, 21, 260 - 273.

${ }^{55} \mathrm{Hu}$, M., and Xia, J.-M. (2010), 'A Preliminary Research on Self-Initiated Expatriation as Compared to Assigned Expatriation,' Canadian Social Science, 6, 169 - 177.

${ }^{56}$ Huang, T.-J., Chi, S.-C., and Lawler, J. (2005), 'The Relationship Between Expatriates' Personality Traits and Their Adjustment to International Assignments,' The International Journal of Human Resource Management, 16, 1656 - 1670.

${ }^{57}$ Hudson, S., and Inkson, K. (2006), 'Volunteer Overseas Development Workers: The Hero's Adventure and Personal Transformation,' Career Development International, 11, 304 - 320.

${ }^{58}$ Inkson, K., Arthur, M.B., Pringle, J., and Barry, S. (1997), 'Expatriate Assignment Versus Overseas Experience: Contrasting Models of International Human Resource Development,' Journal of World Business, 32, $351-368$.

${ }^{59}$ Inkson, K., Carr, S., Edwards, M., Hooks, J., Johnson, D., Thorn, K., and Allfree, N. (2004), 'From Brain Drain to Talent Flow: Views of Kiwi Expatriates,' University of Auckland Business Review, 6, 29 - 39 .

${ }^{60}$ Inkson, K., and Myers, B.A. (2003), “The big OE”: Self-Directed Travel and Career Development,' Career Development International, 8, 170 - 181.

${ }^{61}$ Jokinen, T., Brewster, C., and Suutari, V. (2008), 'Career Capital During International Work Experiences: Contrasting Self-Initiated Expatriate Experiences and Assigned Expatriation,' The international Journal of Human Resource Management, 19, 979 - 998.

${ }^{62}$ Knowles, C. (2006), 'Seeing Race Through the Lens,' Ethnic and Racial Studies, 29, $512-529$.

Knowles, R.D., and Matthiesen, C.W. (2009), 'Barrier Effects of International Borders On Fixed Link Traffic Generation: The Case of Iresundsbron,' Journal of Transport Geography, 17, 155 -165 . 
${ }^{63}$ Konopaske, R., Robie, C., and Ivancevich, J. (2005), 'A Preliminary Model of Spouse Influence on Managerial Global Assignment Willingness,' The International Journal of Human Resource Management, 16, 405 - 426.

Krippendorff, K. (1980), Content Analysis. An Introduction to Its Methodology, London: Sage Publications.

${ }^{64}$ Lauring, J., and Selmer, J. (2009), 'Expatriate Compound Living: An Ethnographic Field Study,' The International Journal of Human Resource Management, 20, 1451 - 1467.

${ }^{65}$ Levels, M., and Dronkers, J. (2008), 'Educational Performance of Native and Immigrant Children From Various Countries of Origin,' Ethnic and Racial Studies, 31, 1404 - 1425.

${ }^{66}$ Lii, S.-Y., and Wong, S.-Y. (2008), 'The Antecedents of Overseas Adjustment and Commitment of Expatriates,' The International Journal of Human Resource Management, 19, 296 - 313.

${ }^{67}$ Lu, M. (1999), 'Do People Move When They Say They Will? Inconsistencies in Individual Migration Behavior,' Population and Environment: A Journal of Interdisciplinary Studies, 20, $467-488$.

${ }^{68}$ Martiniello, M., and Lafleur, J.-M. (2008), 'Towards a Transatlantic Dialogue in the Study of Immigrant Political Transnationalism,' Ethnic and Racial Studies, 31, 645 - 663.

${ }^{69}$ Massey, D.S., and Bartley, K. (2006), 'The Changing Legal Status Distribution of Immigrants: A Caution,' International Migration Review, 39, 469 - 484.

${ }^{70}$ Maxwell, R. (2010), 'Evaluating Migrant Integration: Political Attitudes Across Generations in Europe,' International Migration Review, 44, 25 - 52.

Mayring, P. (2000), Qualitative Inhaltsanalyse. Grundlagen und Techniken (7th ed.), Weinheim: Deutscher StudienVerlag.

${ }^{71}$ Mazzucato, V., and Kabki, M. (2009), 'Small is Beautiful: The Micro-Politics of Transnational Relationships Between Ghanaian Hometown Associations and Communities Back Home,' Global Networks, 9, $227-251$.

${ }^{72}$ McKenna, S., and Richardson, J. (2007), 'The Increasing Complexity of the Internationally Mobile Professional: Issues for Research and Practice,' Cross Cultural Management, 14, 307 - 320.

${ }^{73}$ Meyskens, M., von Glinow, M.A., Werther, W.B., and Clarke, L. (2009), 'The Paradox of International Talent: Alternative Forms of International Assignments,' The International Journal of Human Resource Management, 20, 1439 - 1450.

${ }^{74}$ Milewski, N., and Hamel, C. (2010), 'Union Formation and Partner Choice in a Transnational Context: The Case of Descendants of Turkish Immigrants in France,' International Migration Review, 44, $615-658$.

Millar, J., and Salt, J. (2007), 'Portfolios of Mobility: The Movement of Expertise in Transnational Corporations in Two Sectors - Aerospace and Extractive Industries,' Global Networks, 8, 25 50 .

${ }^{75}$ Moldenhawer, B. (2005), 'Transnational Migrant Communities and Education Strategies Among Pakistani Youngsters in Denmark,' Journal of Ethnic and Migration Studies, 31, 51 - 78.

${ }^{76}$ Myers, B., and Pringle, J. (2005), 'Self-Initiated Foreign Experience as Accelerated Development: Influences of Gender,' Journal of World Business, 40, 421 - 431.

${ }^{77} \mathrm{Na}$ "sholm, M. (2009), 'An Identity Construction Perspective on Careers of Swedish International Itinerants,' Management Revue, 20, 53 - 69.

${ }^{78}$ Oda, E. (2010), 'Ethnic Migration and Memory: Disputes Over the Ethnic Origins of Japanese Brazilians in Japan,' Ethnic and Racial Studies, 33, 515 - 532.

OECD (2012), Model Tax Convention on Income and on Capital 2010: Full Version, OECD Publishing, http://www.keepeek.com/Digital-Asset-Management/oecd/taxation/model-tax-convention-on-income-and-on-capital-2010_9789264175181-en\#page1

${ }^{80}$ Olsen, J.E., and Martins, L.L. (2009), 'The Effects of Expatriate Demographic Characteristics on Adjustment: A Social Identity Approach,' Human Resource Management, 48, 311 - 328.

${ }^{79}$ O'Sullivan, A., and O'Sullivan, S.L. (2008), 'The Performance Challenges of Expatriate Supplier Teams: A Multi-Firm Case Study,' The International Journal of Human Resource Management, 19, $999-1017$.

${ }^{81}$ Painter, G., and Yu, Z. (2010), 'Immigrants and Housing Markets in Mid-Size Metropolitan Areas,' International Migration Review, 44, $442-476$.

${ }^{82}$ Parren as, R.S. (2010), 'Homeward Bound: The Circular Migration of Entertainers Between Japan and the Philippines,' Global Networks, 10, $301-323$.

${ }^{83}$ Paull, B., and Chu, W. (2003), 'Expatriate Assignments - Tax and Non-Tax Considerations,' International Tax Review, 63. 
${ }^{84}$ Peltokorpi, V. (2008), 'Cross-Cultural Adjustment of Expatriates in Japan,' The International Journal of Human Resource Management, 19, 1588 - 1606.

${ }^{85}$ Peltokorpi, V., and Froese, F.J. (2009), 'Organizational Expatriates and Self-Initiated Expatriates: Who Adjusts Better to Work and Life in Japan?' The International Journal of Human Resource Management, 20, 1096 - 1112.

${ }^{86}$ Portes, A. (2009), 'Migration and Development: Reconciling Opposite Views,' Ethnic and Racial Studies, 32, $5-22$.

${ }^{87}$ Portes, A., Escobar, C., and Radford, A.W. (2007), 'Immigrant Transnational Organizations and Development: A Comparative Study,' International Migration Review, 41, 242 - 281.

${ }^{88}$ Preibisch, K. (2010), 'Pick-Your-Own Labor: Migrant Workers and Flexibility in Canadian Agriculture,' International Migration Review, 44, 404 - 441.

${ }^{89}$ Pruthi, S., Wright, M., and Meyer, K.E. (2009), 'Staffing Venture Capital Firms' International Operations,' The International Journal of Human Resource Management, 20, 186 - 205.

${ }^{90}$ Redstone Akresh, I. (2006), 'Occupational Mobility Among Legal Immigrants to the United States,' International Migration Review, 40, 854 - 884.

${ }^{91}$ Reiche, B.S. (2006), 'The Inpatriate Experience in Multinational Corporations: An Exploratory Case Study in Germany,' The International Journal of Human Resource Management, 17, 1572 -1590 .

${ }^{92}$ Richardson, J. (2006), 'Self-Directed Expatriation: Family Matters,' Personnel Review, 35, $469-486$.

${ }^{93}$ Richardson, J., and Mallon, M. (2005), 'Career Interrupted? The Case of the Self-Directed Expatriate,' Journal of World Business, 40, 409 - 420.

${ }^{94}$ Richardson, J., and McKenna, S. (2000), 'Metaphorical "Types" and Human Resource Management: Self-Selecting Expatriates,' Industrial and Commercial Training, 32, 209 - 218.

${ }^{95}$ Richardson, J., and McKenna, S. (2006), 'Exploring Relationships With Home and Host Countries: A Study of Self-Directed Expatriates,' International Journal of Cross Cultural Management, 13, 6-22.

${ }^{96}$ Richardson, J., and Zikic, J. (2007), 'The Darker Side of an International Academic Career,' Career Development International, 12, 164 - 186.

${ }^{97}$ Rosen, P.B., Ekelman, F.B., and Lubbe, E.J. (2000), 'Managing Expatriate Employees: Employment Law Issues and Answers,' Journal of Employment Discrimination Law, 2, 110 123.

${ }^{98}$ Rowthorn, R. (2008), 'The Fiscal Impact of Immigration on the Advanced Economies,' Oxford Review of Economic Policy, 24, 560 - 580.

${ }^{99}$ Sa'nchez Vidal, M.E., Sanz Valle, R., and Arago'n, M.I.B. (2008), 'International Workers' Satisfaction With the Repatriation Process,' The International Journal of Human Resource Management, 19, 1683 - 1702.

${ }^{100}$ Scullion, H., Collings, D.G., and Gunnigle, P. (2007), 'International Human Resource Management in the 21st Century: Emerging Themes and Contemporary Debates,' Human Resource Management Journal, 17, $309-319$.

${ }^{101}$ Selmer, J., and Lauring, J. (2010), 'Self-Initiated Academic Expatriates: Inherent Demographics and Reasons to Expatriate,' European Management Review, 7, 169 - 179.

${ }^{102}$ Selmer, J., and Lauring, J. (2011a), 'Marital Status and Work Outcomes of Self-Initiated Expatriates: Is There a Moderating Effect of Gender?' Cross Cultural Management: An International Journal, 18, $198-213$.

${ }^{103}$ Selmer, J., and Lauring, J. (2011b), 'Acquired Demographics and Reasons to Relocate Among Self-Initiated Expatriates,' The International Journal of Human Resource Management, 22, $2055-2070$.

${ }^{104}$ Siljanen, T., and La"msa“, A.-M. (2009), 'The Changing Nature of Expatriation: Exploring Cross-Cultural Adaptation Through Narrativity,' The International Journal of Human Resource Management, 20, 1468 - 1486.

${ }^{105}$ Snel, E., Engbersen, G., and Leerkes, A. (2006), 'Transnational Involvement and Social Integration,' Global Networks, 6, $285-308$.

${ }^{106}$ Soehl, T., and Waldinger, R. (2010), 'Making the Connection: Latino Immigrants and Their Cross-Border Ties,' Ethnic and Racial Studies, 33, 1489 - 1510.

${ }^{107}$ Sparrow, P.R. (2007), 'Globalization of HR at Function Level: Four UK-Based Case Studies of the International Recruitment and Selection Process,' The International Journal of Human Resource Management, 18, 845 - 867. 
Sparrow, P., Brewster, C., and Harris, H. (2004), Globalizing Human Resource Management, London: Routledge.

Spieß, E., and Wittmann, A. (1999), 'Motivational Phases Associated With the Foreign Placement of Managerial Candidates: An Application of the Rubicon Model of Action Phases,' The International Journal Human Resource Management, 10, 891 - 905.

${ }^{108}$ Starr, T.L., and Currie, G. (2009), "Out of Sight but Still in the Picture": Short-Term International Assignments and the Influential Role of Family,' International Journal of Human Resource Management, 20, 1421 - 1438.

Stone, I., and Stubbs, C. (2007), 'Enterprising Expatriates: Lifestyle Migration and Entrepreneurship in Rural Southern Europe,' Entrepreneurship and Regional Development: An International Journal, 19, 433 - 450. doi:10.1080/08985620701552389.

Stuart, E. (2010), 'Art. 4 (2) of the OECD Model Convention: Practice and Case Law,' in Residence of Individuals Under Tax Treaties and EC Law, ed. G. Maisto, Amsterdam: IBFD Publications BV, pp. $181-194$.

${ }^{109}$ Surak, K. (2008), 'Convergence in Foreigners' Rights and Citizenship Policies? A Look at Japan,' International Migration Review, 42, 550 - 575.

${ }^{110}$ Suutari, V., and Brewster, C. (2000), 'Making Their Own Way: International Experience Through Self-Initiated Foreign Assignments,' Journal of World Business, 35, 417 - 436.

${ }^{111}$ Tams, S., and Arthur, M.B. (2007), 'Studying Careers Across Cultures: Distinguishing International, Cross-Cultural, and Globalization Perspectives,' Career Development International, $12,86-98$.

${ }^{112}$ Tharenou, P. (2009), 'Self-Initiated International Careers: Gender Differences and Career Outcomes,' in Maintaining Focus, Energy and Options Over the Career, eds. S.G. Baugh and S.E. Sullivan, Charlotte, NC: Information Age Publishing, pp. 197 - 226.

${ }^{113}$ Tharenou, P. (2010), 'Women's Self-Initiated Expatriation as a Career Option and Its Ethical Issues,' Journal of Business Ethics, 95, 73 - 88.

${ }^{114}$ Tharenou, P., and Caulfield, N. (2010), 'Will I Stay or Will I Go? Explaining Repatriation by Self-Initiated Expatriates,' Academy of Management Journal, 53, 1009 - 1028.

${ }^{115}$ Tharenou, P., and Harvey, M. (2006), 'Examining the Overseas Staffing Options Utilized by Australian Headquartered Multinational Corporations,' International Journal of Human Resource Management, 17, 1095 - 1114.

${ }^{116}$ Tharmaseelan, N., Inkson, K., and Carr, S.C. (2010), 'Migration and Career Success: Testing a Time-Sequenced Model,' Career Development International, 15, 218 - 238.

${ }^{117}$ Thite, M., Srinivasan, V., Harvey, M., and Valk, R. (2009), 'Expatriates of Host-Country Origin: "Coming Home to Test the Waters", The International Journal of Human Resource Management, 20, $269-285$.

${ }^{118}$ Thomas, K.J.A. (2007), 'Child Mortality and Socioeconomic Status: An Examination of Differentials by Migration Status in South Africa,' International Migration Review, 41, 40 - 74.

${ }^{119}$ Thorn, K. (2009), 'The Relative Importance of Motives for International Self-Initiated Mobility,' Career Development International, 14, 441 - 464.

${ }^{120}$ Trotz, D.A. (2006), 'Rethinking Caribbean Transnational Connections: Conceptual Itineraries,' Global Networks, 6, $41-59$.

United Nations (1998), Recommendations on Statistics of International Migration, Statistical Papers Series M, 58, 1, New York: Author.

${ }^{123}$ Vance, C. (2005), 'The Personal Quest for Building Global Competence: A Taxonomy of SelfInitiating Career Path Strategies for Gaining Business Experience Abroad,' Journal of World Business, 40, $374-385$.

121 van der Heijden, J.A.V., van Engen, M.L., and Paauwe, J. (2009), 'Expatriate Career Support: Predicting Expatriate Turnover and Performance,' The International Journal of Human Resource Management, 20, $831-845$.

${ }^{122}$ van Meeteren, M., Engbersen, G., and van San, M. (2009), 'Striving for a Better Position: Aspirations and the Role of Cultural, Economic, and Social Capital for Irregular Migrants in Belgium,' International Migration Review, 43, 881 - 907.

Vroom, V.H. (1964), Work and Motivation, New York: Wiley.

${ }^{124}$ Waldinger, R. (2007), 'Did Manufacturing Matter? The Experience of Yesterday's Second Generation: A Reassessment,' International Migration Review, 41, 3 - 39.

${ }^{125}$ Waldinger, R. (2008), 'Between "Here" and "There": Immigrant Cross-Border Activities and Loyalties,' International Migration Review, 42, 3 - 29. 
${ }^{126}$ Walsh, J., and Zhu, Y. (2007), 'Local Complexities and Global Uncertainties: A Study of Foreign Ownership and Human Resource Management in China,' The International Journal of Human Resource Management, 18, 249 - 267.

${ }^{127}$ Wang, M., and Takeuchi, R. (2007), 'The Role of Goal Orientation During Expatriation: A CrossSectional and Longitudinal Investigation,' Journal of Applied Psychology, 92, 1437 - 1445.

Weiner, B. (1985), 'An Attributional Theory of Achievement Motivation and Emotion,' Psychological Review, 92, $548-573$.

${ }^{128}$ Welch, D.E., Welch, L.S., and Worm, V. (2007), 'The International Business Traveller: A Neglected but Strategic Human Resource,' The International Journal of Human Resource Management, 18, 173 - 183.

${ }^{129}$ Wiles, J. (2008), 'Sense of Home in a Transnational Social Space: New Zealanders in London,' Global Networks, 8, $116-137$.

${ }^{130}$ Williams, A.M. (2007), 'International Labour Migration and Tacit Knowledge Transactions: A Multi-Level Perspective,' Global Networks, 7, 29 - 50.

${ }^{131}$ Yamanaka, K. (2005), 'Changing Family Structures of Nepalese Transmigrants in Japan: SplitHouseholds and Dual-Wage Earners,' Global Networks, 5, 337 - 358.

${ }^{132}$ Zikic, J., Bonache, J., and Cerdin, J.-L. (2010), 'Crossing National Boundaries: A Typology of Qualified Immigrants' Career Orientations,' Journal of Organizational Behavior, 31, 667 - 686. 